Part of Journal of Research of the National Bureau of Standards, Volume 26, May 1941

\title{
COLORIMETRIC DETERMINATION OF PHOSPHORUS IN STEEL AND CAST IRON
}

\author{
By John L. Hague and Harry A. Bright
}

\section{ABSTRACT}

A colorimetric method is described for the determination of phosphorus in steels and irons. The phosphomolybdenum blue reaction is utilized, and the transmittancy of the colored solution is measured with a photoelectric colorimeter and a Corning Lantern Shade Yellow filter, No. 349. Provision is made for the effects of arsenic and silicon, and a method of compensating for the color of alloying constituents is given. An accuracy of \pm 0.003 percent was indicated for steels whose phosphorus content ranged from 0.01 to 0.11 percent. With cast irons containing 0.25 to 0.80 percent of phosphorus, values accurate to $\pm \mathbf{0 . 0 2}$ percent were obtained. A single determination of phosphorus in steel can be made in about 20 minutes, and a set of eight determinations can be completed in approximately 45 minutes.

\section{CONTENTS}

I. Introduction

II. Apparatus and reagents_...

1. Apparatus _....... 406

2. Reagents

III. Procedure.

IV. Results._.

V. Discussion

\section{INTRODUCTION}

The most widely used method for the determination of phosphorus in steels and irons involves its precipitation as the yellow ammonium phosphomolybdate, and subsequent titration of the phosphomolybdate with a standard alkali solution. The development of improved filter photometers has directed attention to the possibility of using rapid colorimetric or turbidimetric methods for the determination of phosphorus in ferrous materials, and a number of photometric procedures for this determination have been published. Koch ${ }^{1}$ described a turbidimetric method based on the reaction of the phosphomolybdate ion with strychnine. Murray and Ashley ${ }^{2}$ used the yellow phosphovanadomolybdate complex, and measured the extinction coefficient of the solution with a Pulfrich step-photometer and a suitable filter. Bursuk ${ }^{3}$ employed the phosphomolybdenum blue complex for

1 Arch. Eisenhüttenw. 12, 69 (1938).

Ind. Eng. Chem., Anal. Ed. 10, 5 (1938).

3 Zavodskaya Lab. 8, 12 (1939). 
the determination of phosphorus in carbon steels, and measured the color intensity of the solution with a photoelectric colorimeter.

The phosphomolybdenum blue reaction has been used for many years in biochemical work for the determination of phosphorus. A summary of the different reducing agents employed, and the methods used to obtain the "blue compound" is given by Snell and Snell ${ }^{4}$ and by Yoe. ${ }^{5}$ The sensitivity of the reaction is of particular value for steels of low phosphorus content $(\mathrm{P}<0.03$ percent). The intensity of the blue color can be measured with simple apparatus, and relatively high percentages of alloying elements wnich give colored ions can be tolerated, because the corrections are small and conveniently made.

This paper reports an application of the phosphomolybdenum blue reaction to the determination of phosphorus in steels and irons. A procedure has been developed in which a reagent containing hydrazine sulfate and ammonium molybdate is used to form the blue compound. This type of reagent, used by Morris and Calvery ${ }^{6}$ for the colorimetric determination of arsenic, gives with the phosphate ion a stable phosphomolybdenum blue complex with but little background color. The sample is dissolved in diluted nitric acid (sp gr 1.20), a definite amount of perchloric acid is added, and the solution is then evaporated to fumes of perchloric acid. Perchloric acid is used to remove the nitric acid, and to insure the oxidation of all phosphorus to the ortho acid; the use of a definite amount provides for the proper adjustment of the initial acidity. Water and a solution of sodium sulfite are added to the cooled residue, and the solution is heated to boiling to reduce the iron. Phosphorus is then converted to the blue compound by adding a solution containing hydrazine sulfate and ammonium molybdate and heating at $90^{\circ}$ for about 5 minutes. The transmittancy of the colored solution is measured with a photoelectric colorimeter (comparator). The quantity of phosphorus is read from a standard curve or table prepared from data obtained by treating steels containing known amounts of phosphorus in the same manner as was used for the unknown. A single determination can be made in about 20 minutes, and a set of eight determinations can be completed in approximately 45 minutes.

\section{APPARATUS AND REAGENTS}

\section{APPARATUS}

A photoelectric colorimeter of the Evelyn ${ }^{7}$ type was used in most of the work. The light-sensitive cell is an Electrocell, and the current-measuring instrument is a low-resistance $(50-\mathrm{ohm})$ microammeter ( 0 to 100 microamperes). A Pyrex test tube ( 16 by 150 $\mathrm{mm}$ ) is used as an absorption cell. ${ }^{8}$ The filter is a Corning Lantern Shade Yellow, No. 349.

\footnotetext{
F. D. Snell and C. T. Snell, Colorimetric Methods of Analysis, vol. 1 (D. Van Nostrand Co., Inc., New York, N. Y., 1936).

s. H. Yoe, Photometric Chemical Analysis, vol. 1 (J. Wiley \& Sons, New York, N. Y., 1928).

Ind. Eng. Chem., Anal. Ed. 9, 448 (1937).

7 J. Biol. Chem. 115, 63 (1936).

8 The effective thickness of a column of liquid in a tube of this diameter is equivalent to approximately $13 \mathrm{~mm}$. Transmittancy measurements were made on a number of tubes when filled with water and when filled with a solution containing the color developed by approximately $30 \mu \mathrm{g}$ of phosphorus in a volume of $50 \mathrm{ml}$. The tubes which gave transmittancy readings identical with those of the tube used to prepare a calibration curve were kept as a reserve supply of matched tubes.
} 


\section{REAGENTS}

Diluted nitric acid (sp gr 1.20).-Add $380 \mathrm{ml}$ of nitric acid (sp gr $1.42)$ to $620 \mathrm{ml}$ of water.

Perchloric acid (60 percent).

Diluted hydrobromic acid (1+4).-Dilute $20 \mathrm{ml}$ of hydrobromic acid (48 percent) with $80 \mathrm{ml}$ of water.

Sodium sulfite solution (10 percent).-Dissolve $100 \mathrm{~g}$ of anhydrous sodium sulfite in $500 \mathrm{ml}$ of water, dilute to $1,000 \mathrm{ml}$, and filter.

Hydrazine sulfate solution (0.15 percent).-Dissolve $1.5 \mathrm{~g}$ of hydrazine sulfate in $1,000 \mathrm{ml}$ of water.

Ammonium molybdate solution (2 percent in $11 \mathrm{~N} \mathrm{H}_{2} \mathrm{SO}_{4}$ ). - Add 300 $\mathrm{ml}$ of sulfuric acid (sp gr 1.84) to $500 \mathrm{ml}$ of water and cool. Dissolve $20 \mathrm{~g}$ of ammonium molybdate in the solution and dilute to $1,000 \mathrm{ml}$ with water.

Ammonium molybdate-hydrazine sulfate reagent.-Dilute $25 \mathrm{ml}$ of the ammonium molybdate solution to $80 \mathrm{ml}$ with water, add $10 \mathrm{ml}$ of the hydrazine sulfate solution, and dilute to $100 \mathrm{ml}$ with water. This solution is not stable and should be prepared as needed.

\section{PROCEDURE}

Carbon steel.-Transfer $50 \mathrm{mg}$ of the sample to a 125-ml Erlenmeyer flask and add $5 \mathrm{ml}$ of diluted nitric acid (sp gr 1.20). Heat until the sample is in solution. Add $3 \mathrm{ml}$ of perchloric acid (60 percent) from a transfer pipette. Evaporate the solution to fuming, and fume gently until all of the nitric acid is removed, usually 3 to 4 minutes. ${ }^{9}$ Cool somewhat ${ }^{10}$ and add $10 \mathrm{ml}$ of water and $15 \mathrm{ml}$ of the sodium sulfite solution. Heat the solution to boiling and boil gently for 20 to 30 seconds. ${ }^{11}$ Add $20 \mathrm{ml}$ of the ammonium molybdate-hydrazine sulfate reagent, heat to about $90^{\circ} \mathrm{C}$, and allow to digest at that temperature for 4 to 5 minutes. Then heat the solution just to boiling temperature, but do not boil. ${ }^{12}$ Cool rapidly to room temperature, transfer the solution to a $50-\mathrm{ml}$ volumetric flask, and dilute to the mark with a diluted solution $(1+4)$ of the ammonium molybdate-hydrazine sulfate reagent. Mix thoroughly, transfer a portion of the solution to the cell (a matched test tube), and measure the percentage transmittancy of the solution, the indicator of the microammeter having been previously adjusted to 100-percent transmittancy for a cell filled with water. The percentage of phosphorus is obtained from a calibration curve or table prepared from data obtained by carrying steels containing known amounts of phosphorus through all the steps of the method.

Alloy steels.-For steels containing less than 2 percent of chromium, 5 percent of vanadium, or 35 percent of nickel, proceed as with carbon steels. If the sample is insoluble in diluted nitric acid (high-chromium steels), add $3 \mathrm{ml}$ of diluted hydrochloric acid $(1+1)$ to the nitric acid solution. If the steel contains more than 2 percent of chromium, 5 percent of vanadium, or 35 percent of nickel, a separate

\footnotetext{
At this stage the neck of the flask becomes dry, and the perchloric acid refluxes on the walls of the flask.

10 When the arsenic content of the sample exceeds 0.05 percent, this element should be eliminated as follows: Add $5 \mathrm{ml}$ of diluted hydrobromic acid $(1+4)$ to the cool perchloric acid solution of the sample, evapo. rate to fuming and fume gently to remove the hydrobromic acid. The interference of as much as 0.25 percent of arsenic can be avoided by this treatment.

11 The brown coloration which appears when the sulfite is first added should disappear completely.

12 Alternatively, the blue coloration may be developed with less attention by digesting for 15 to 20 minutes on the steam bath $\left(85^{\circ}\right.$ to $\left.90^{\circ} \mathrm{C}\right)$.
} 
50-mg portion is taken to obtain the correction for the absorption due to the solution of the sample. This sample is carried through all the steps of the method, except that $20 \mathrm{ml}$ of diluted sulfuric acid $(8+92)$ is substituted for the $20 \mathrm{ml}$ of ammonium molybdate-hydrazine sulfate reagent specified in the procedure, and the final dilution to $50 \mathrm{ml}$ is made with water. The correction for the transmittancy of the unreduced solution is made as described in section IV.

Cast iron.-Transfer a 100-mg sample to a 125-ml Erlenmeyer flask, and dissolve the sample in $25 \mathrm{ml}$ of diluted nitric acid (sp gr 1.20). Boil until nitrous fumes are expelled, cool, and dilute the solution to exactly $100 \mathrm{ml}$. Allow the graphite to settle, and pipette a 5 -ml aliquot portion into a $125-\mathrm{ml}$ Erlenmeyer flask. Add $3 \mathrm{ml}$ of perchloric acid (60 percent) and proceed as with carbon steels, eliminating arsenic by treatment with hydrobromic acid.

\section{RESULTS}

The results obtained with a series of carbon steels are shown graphically in figure 1. It will be seen that Beer's law holds up to

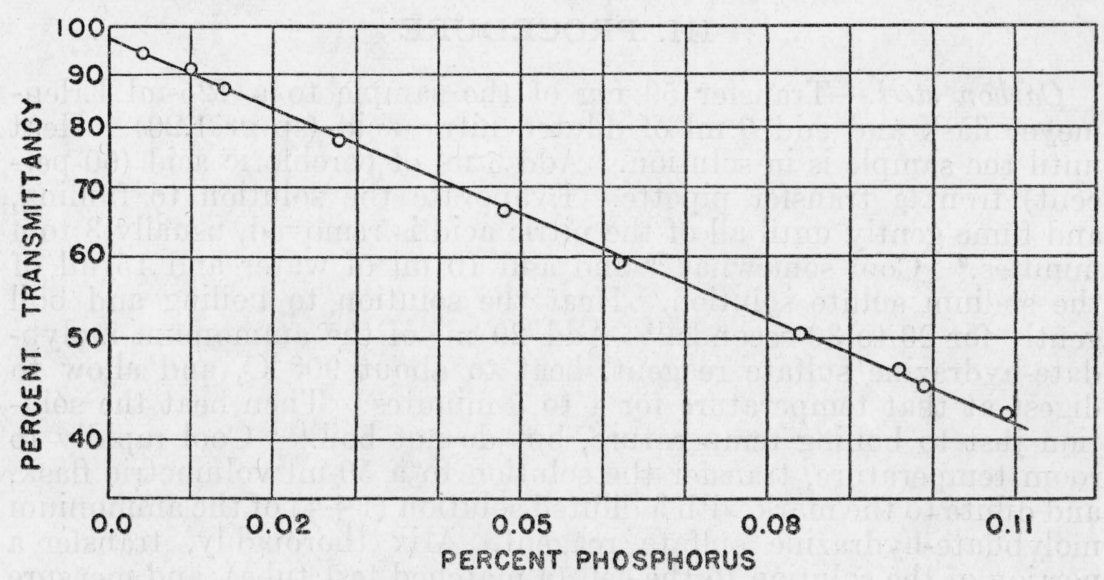

Figure 1.-Curve showing conformance to Beer's law.

0.11 percent of phosphorus, within an experimental error of about 0.003 percent of phosphorus. The curve does not pass through the 100-percent transmittancy point, because no attempt was made to correct the measurements for the small amount of absorption due to iron, to phosphate in the reagents, to the small amount of arsenic (approximately 0.01 percent) generally present in steels, and to other blank effects. Each new lot of reagents, therefore, must be carefully tested by carrying standards through all the steps of the method in order to check the calibration curve.

The values for individual determinations of phosphorus may be read from a graph of the type illustrated in figure 1, or from a table in which the percentage of phosphorus corresponding to various percentage transmittancy values has been calculated from the equation $\log T_{2}-\log T_{1}=k\left(\ddot{C}_{2}-C_{1}\right)$. Using the percentage transmittancy obtained on NBS Standard Samples 8e and 55a as standards, a table 
of phosphorus-transmittancy values was calculated. ${ }^{13}$ Individual values for the carbon steel samples were read from this table, and the results obtained are shown in table 1. The maximum error is 0.007 percent of phosphorus, and the average error is about 0.002 percent.

\section{TABLE 1.-Results obtained by the procedure recommended for carbon steels}

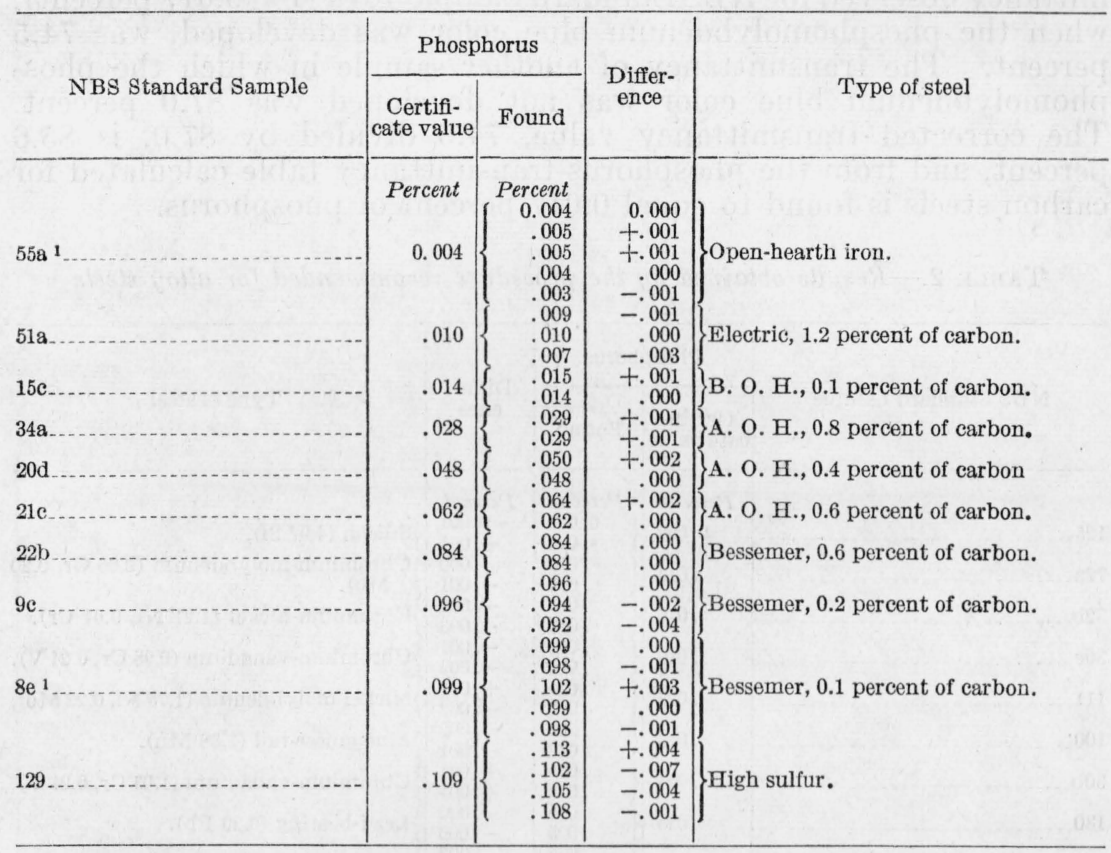

1 Used as a standard, but data given to show the precision of single determinations.

The results obtained on alloy steels with phosphorus contents ranging from 0.01 to 0.03 percent are shown in table 2 . The maximum error is 0.003 percent, and the average error is about $0.001_{2}$

13 Example:

A transmittancy value $\left(T_{1}\right)$ of 94.5 percent was observed for NBS Standard Sample 55a, which contains 0.004 percent $\left(C_{1}\right)$ of phosphorus. A transmittancy value $\left(T_{2}\right)$ of 45.0 percent was observed for NBS Standard Sample $8 \mathrm{e}$, which contains 0.099 percent $\left(C_{2}\right)$ of phosphorus. Substituting in the above equation, solve for $k$ :

$$
\begin{aligned}
& \begin{array}{ll}
\log T_{1}=1.9754 & C_{1}=0.004 \\
\log T_{2}=1.6532 & C_{2}=0.099
\end{array} \\
& k=\frac{\log T_{2}-\log T_{1}}{C_{2}-C_{1}}=\frac{1.6532-1.9754}{0.099-0.004}=-3.39 .
\end{aligned}
$$

Calculate the intercept $T_{0}$ (where $C_{0}=0.000$ percent):

$$
\begin{aligned}
& \log T_{2}=1.6532 \quad C_{2}=0.099 \\
& \log T_{0}=\log T_{2}-k\left(C_{2}-C_{0}\right) \\
& \log \begin{array}{l}
T_{0}=1.6532-(-3.39 \times 0.099)=1.9888 \\
T_{0}=97.5
\end{array}
\end{aligned}
$$

To calculate the percentage of phosphorus $\left(C_{x}\right)$ equivalent to an observed percent transmittancy $\left(T_{x}\right)$ value:

$$
\begin{aligned}
& T_{0}=97.5 ; \log T_{0}=1.9888 \\
& T_{x}=\text { transmittancy for which a phosphorus equivalent is wanted. }
\end{aligned}
$$

$$
\text { percentage of phosphorus } \begin{aligned}
=C_{x}-C_{0}=\frac{\log T_{x}-\log T_{0}}{k}=\frac{\log T_{0}-\log T_{x}}{-k} \\
=C_{x}=\frac{1.9888-\log T_{x}}{3.39}
\end{aligned}
$$

These data apply only to the Evelyn-type colorimeter and tubes used in this work, but are given to show the method of calculation employed. 
percent of phosphorus. The percentage of phosphorus was read from the phosphorus-transmittancy table calculated for carbon steels. The percentage transmittancy observed for NBS Standard Samples 73, 101, 101a, and 121 (high-chromium steels) was corrected for the absorption due to the solution of the sample in which the phosphomolybdenum blue color was not developed. For example, the transmittancy observed for NBS Standard Sample 101a ( $\mathrm{P}=0.017$ percent), when the phosphomolybdenum blue color was developed, was 74.5 percent. The transmittancy of another sample in which the phosphomolybdenum blue color was not developed was 87.0 percent. The corrected transmittancy value, 74.5 divided by 87.0 , is 85.6 percent, and from the phosphorus-transmittancy table calculated for carbon steels is found to equal 0.017 percent of phosphorus.

TABLE 2.-Results obtained by the procedure recommended for alloy steels

\begin{tabular}{|c|c|c|c|c|}
\hline \multirow{2}{*}{ NBS Standard Sample } & \multicolumn{2}{|c|}{ Phosphorus } & \multirow{2}{*}{$\begin{array}{l}\text { Differ- } \\
\text { ence }\end{array}$} & \multirow{2}{*}{ Type of steel } \\
\hline & $\begin{array}{c}\text { Certifi- } \\
\text { cate value }\end{array}$ & Found & & \\
\hline & Percent & Percent & Percent & \\
\hline $125 \ldots$ & 0.008 & $\begin{array}{l}0.007 \\
\text { a. } 009\end{array}$ & $\begin{array}{r}-0.001 \\
+.001\end{array}$ & Silicon (4.97 Si) \\
\hline $72 a-$. & .016 & $\begin{array}{l}.016 \\
.015\end{array}$ & $\begin{array}{r}.000 \\
-.001\end{array}$ & $\left\{\begin{array}{l}\text { Chromium-molybdenum }(0.66 \mathrm{Cr}, 0.20 \\
\text { Mo). }\end{array}\right.$ \\
\hline $32 b_{\ldots} \ldots$ & .016 & .015 & $\begin{array}{l}-.001 \\
-.003\end{array}$ & Chromium-nickel (1.21 Ni, $0.64 \mathrm{Cr})$ \\
\hline $30 c_{-}$ & .019 & $\begin{array}{l}.018 \\
.016\end{array}$ & $\begin{array}{l}-.001 \\
-.003\end{array}$ & Chromium-vanadium $(0.98 \mathrm{Cr}, 0.24 \mathrm{~V})$. \\
\hline $111 \ldots$ & .023 & $\begin{array}{l}.024 \\
.021\end{array}$ & $\begin{array}{l}+.001 \\
-.002\end{array}$ & Nickel-molybdenum (1.75 Ni, $0.22 \mathrm{Mo})$. \\
\hline $100 \ldots$ & .023 & .025 & $\begin{array}{r}+.002 \\
-.001\end{array}$ & Manganese-rail (1.38 Mn). \\
\hline $30 b_{-. .}$ & .024 & .025 & $\begin{array}{l}+.001 \\
+.001\end{array}$ & Chromium-vanadium $(1.03 \mathrm{Cr}, 0.21 \mathrm{~V})$. \\
\hline 130 & .025 & .025 & $\begin{array}{r}.000 \\
-.000\end{array}$ & Lead-bearing $(0.20 \mathrm{~Pb})$ \\
\hline $33 b_{\ldots}$ & .037 & $\begin{array}{l}.035 \\
.035\end{array}$ & $\begin{array}{l}-.002 \\
-.002\end{array}$ & Nickel $(3.48 \mathrm{Ni})$ \\
\hline 101. & .010 & $\begin{array}{l}\text { b. } 012 \\
\text { b. } 012\end{array}$ & $\begin{array}{r}+.002 \\
+.002\end{array}$ & Chromium-nickel (17.6 Cr, 8.4 Ni). \\
\hline $121 .-$ & .016 & $\begin{array}{l}\text { b. } 018 \\
\text { b. } 018\end{array}$ & $\begin{array}{l}+.002 \\
+.002\end{array}$ & $\begin{array}{l}\text { Chromium-nickel, titanium-bearing } \\
(17.8 \mathrm{Cr}, 9.0 \mathrm{Ni}, 0.39 \mathrm{Ti}) .\end{array}$ \\
\hline 1018 & .017 & $\begin{array}{l}\text { b. } 017 \\
\text { b. } 017\end{array}$ & $\begin{array}{r}.000 \\
.000\end{array}$ & Chromium-nickel $(18.3 \mathrm{Cr}, 9.0 \mathrm{Ni})$ \\
\hline $73 \ldots$ & .023 & $\begin{array}{l}\text { b. } 021 \\
\text { b. } 021\end{array}$ & $\begin{array}{l}-.002 \\
-.002\end{array}$ & Chromium (13.9 Cr) \\
\hline
\end{tabular}

- Two drops (0.05 ml) HF present during solution of sample.

b Result obtained by correcting for absorption due to the sample. See section IV.

The results obtained by the procedure for cast irons are shown in table 3. A table of phosphorus-transmittancy values was calculated, using $4 \mathrm{e}$ and $7 \mathrm{c}$ as standards, and the values given were read from this table. The maximum error is 0.02 percent, and the average error is less than 0.01 percent of phosphorus. A few experiments indicated that the color obtained from a given amount of phosphorus was constant when the amount of iron present was varied from 5 to $50 \mathrm{mg}$. For cast irons, values read from the table prepared for carbon steels, multiplied by 10 to compensate for the difference in weight of sample, were almost as accurate as those shown in table 3. 
TABLE 3.-Results obtained by the procedure recommended for cast irons

\begin{tabular}{|c|c|c|c|}
\hline \multirow[b]{2}{*}{ NBS Standard Sample } & \multicolumn{2}{|c|}{ Phosphorus } & \multirow[b]{2}{*}{ Difference } \\
\hline & $\begin{array}{c}\text { Certificate } \\
\text { value }\end{array}$ & Found & \\
\hline & Percent & $\begin{array}{l}\text { Percent } \\
0.11\end{array}$ & ${ }_{0.00}^{\text {Percent }}$ \\
\hline $4 e^{1} \ldots \ldots$ & 0.109 & $\begin{array}{r}.11 \\
.11 \\
.12\end{array}$ & $\begin{array}{r}.00 \\
+.01\end{array}$ \\
\hline $5 \mathrm{~g}$ & .261 & $\begin{array}{l}.26 \\
.24\end{array}$ & $\begin{array}{r}.00 \\
-.02 \\
\end{array}$ \\
\hline $6 \mathrm{~d}$ & .486 & $\begin{array}{r}.01 \\
.50 \\
.49\end{array}$ & $\begin{array}{r}+.01 \\
.00\end{array}$ \\
\hline $7 e^{1} \ldots \ldots \ldots$ & .778 & $\begin{array}{l}.78 \\
.78 \\
.78\end{array}$ & $\begin{array}{l}.00 \\
.00\end{array}$ \\
\hline
\end{tabular}

Used as a standard.

\section{DISCUSSION}

The spectral transmittancies of the phosphomolybdenum blue compound, of iron, and iron plus chromium, and the spectral transmission of the Corning filter (No. 349), were obtained with a Coleman

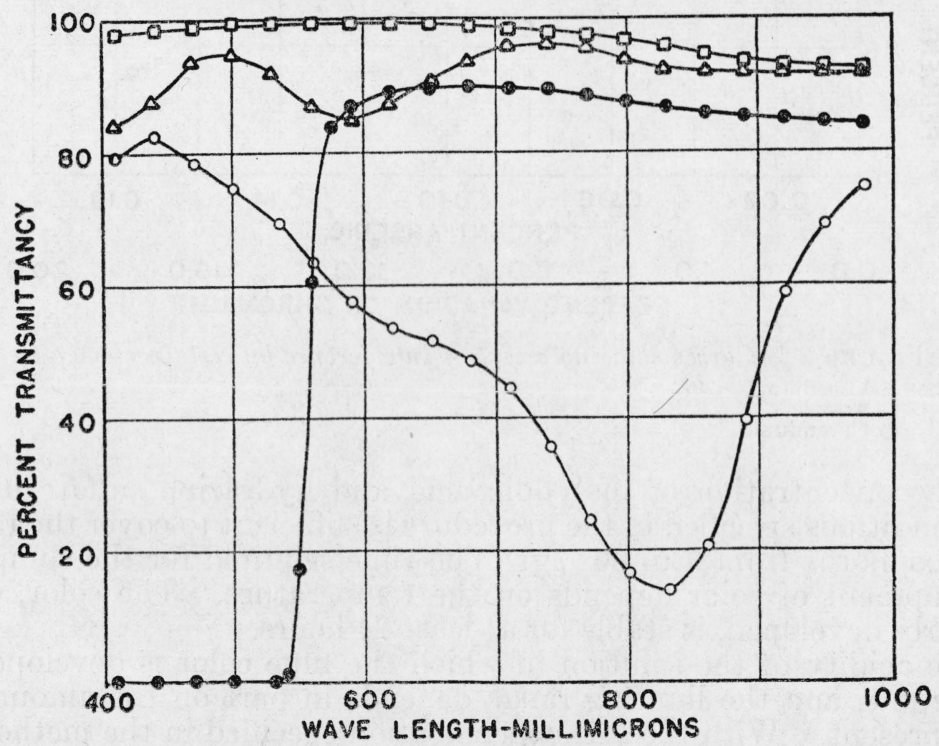

FIGURE 2.-Curves showing regions of absorption.

- Filter.

Phosphomolybdenum blue complex.

$\triangle 50$-mg NBS Standard Sample 73 (14 percent of $\mathrm{Cr}$ ).

50-mg NBS Standard Sample 55a (ingot iron).

$D M$ spectrophotometer (model $10 \mathrm{~S}$ ). The data are shown in figure 2. It will be noted that the maximum absorption due to the phosphomolybdenum blue compound occurs at approximately $830 \mathrm{~m} \mu$. A few measurements made at this wavelength and at $650 \mathrm{~m} \mu$ indicate that the solutions follow Beer's law at both wavelengths. Measure- 
ments made on the Evelyn-type colorimeter were limited to the region from $550 \mathrm{~m} \mu$ to approximately $700 \mathrm{~m} \mu$ by the filter and by the spectral sensitivity of the photocell.

Roe, Irish, and Boyd ${ }^{14}$ have studied the phosphomolybdenum blue reaction and have summarized the conditions which must be controlled: (1) the concentration of molybdic acid, (2) the concentration of the reducing agent, (3) the time allowed for completion of the reaction, (4) the hydrogen ion concentration, (5) the presence of salts, and (6) the amount of phosphorus in the sample being analyzed.

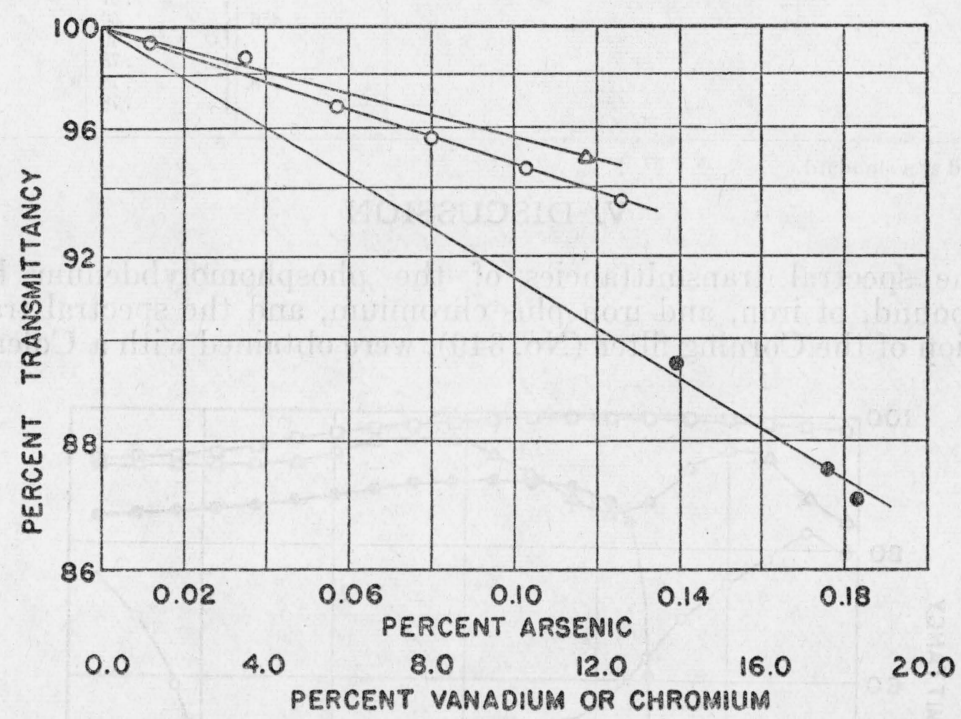

FIGURE 3.-Curves showing extent of interference by certain elements. $\triangle$ Vanadium.

O Arsenic

- Chromium.

The concentration of molybdic acid and hydrazine sulfate under the conditions specified in the procedure is sufficient to cover the range of phosphorus from 0 to $60 \mu \mathrm{g}$. The time required for the complete development of color depends on the temperature. The color, once properly developed, is stable for at least 24 hours.

The acidity of the solution in which the blue color is developed is important, and the limiting range depends in part on the amount of salts present. With the salt concentration specified in the method of Roe, Irish, and Boyd, the permissible range of acidity is given as $0.9 \mathrm{~N}$ to $1.9 \mathrm{~N}$ sulfuric acid. Tests of the effect of acidity in the procedure given in this paper were subject to the uncertainty of the amount of residual sulfurous acid. However, experiments in which the acidity of the ammonium molybdate solution was varied from $5 \mathrm{~N}$ to $16 \mathrm{~N}$ sulfuric acid (corresponding to an acidity of $0.5 \mathrm{~N}$ to $1.6 \mathrm{~N}$ sulfuric acid in the final solution) indicated that (1) some bleaching of the color occurs in solutions approximating $1.6 \mathrm{~N}$ in sulfuric acid,

14 J. Biol. Chem. 67, 580 (1926). 
and (2) erratic results are obtained when the acidity is less than 0.8 $N$ sulfuric acid.

Arsenate gives a molybdenum-blue reaction similar to that of phosphate, and the extent of this interference is shown in figure 3. Experiments indicate that 0.05 percent of arsenic may be present without leading to an error greater than 0.003 percent of phosphorus.

It has been stated that silicon gives a molybdenum-blue compound. This reaction, however, does not occur under the conditions given in the recommended procedure. Large amounts of silicon give rise to an objectionable turbidity, and a few experiments made with a highsilicon steel, NBS Standard Sample 125, indicate that this difficulty can be overcome by adding 2 drops (about $0.05 \mathrm{ml}$ ) of hydrofluoric acid to the original nitric-perchloric acid solution of the sample, and evaporating to fumes as directed in the procedure.

Copper, nickel, chromium, and vanadium do not interfere with the development of the phosphomolybdenum blue color, but give colored ions which may interfere unless proper compensation is made. Experiments indicate that as much as 35 percent of nickel, 15 percent of copper, 5 percent of vanadium, or 2 percent of chromium may be present without leading to an error greater than 0.002 percent of phosphorus, when the calibration curve is prepared from carbon steels. The extent of the interference of chromium and vanadium is shown in figure 3. When the above-mentioned elements are present in amounts greater than those indicated, correct results can be obtained by preparing a calibration curve with the same type of material being tested, or alternatively, a correction can be applied by measuring the transmittancy of a solution of the sample in which the phosphomolybdenum blue color is not developed.

Washington, January 8, 1941. 